\title{
Genetic Diversity of Spiroplasma citri Strains from Different Regions, Hosts, and Isolation Dates
}

\author{
A. F. S. Mello, R. K. Yokomi, U. Melcher, J. C. Chen, A. C. Wayadande, and J. Fletcher
}

First, fifth, and sixth authors: Oklahoma State University, Department of Entomology \& Plant Pathology, Stillwater 74078; second and fourth authors: United States Department of Agriculture-Agricultural Research Service, Parlier, CA 93648; and third author: Oklahoma State University, Department of Biochemistry and Molecular Biology, Stillwater 74078.

Accepted for publication 20 April 2008.

\begin{abstract}
Mello, A. F. S., Yokomi, R. K., Melcher, U., Chen, J. C., Wayadande, A. C., and Fletcher, J. 2008. Genetic diversity of Spiroplasma citri strains from different regions, hosts, and isolation dates. Phytopathology 98:960968.

Spiroplasma citri, a phloem-limited pathogen, causes citrus stubborn disease (CSD). Losses due to CSD in California orchards have grown over the past decade. To investigate the possibility of introduction or emergence of a new strain, a study of genetic diversity among $S$. citri strains from various locations was conducted using random amplified polymorphism DNA-polymerase chain reaction (RAPD-PCR) of 35 strains cultured from 1980 to 1993, and of 35 strains cultured from 2005 to 2006. Analysis using 20 primer pairs revealed considerable diversity among

strains. However, no unique genetic signatures were associated with recently collected strains compared with those collected 15 to 28 years ago, and no geographically associated pattern was distinguishable. S. citri strains from carrot and daikon radish contain some unique DNA fragments, suggesting some host plant influence. Multiple strains from single trees also showed genetic diversity. Sequencing of five RAPD bands that differed among strains showed that diversity-related gene sequences include virus fragments, and fragments potentially encoding a membrane lipoprotein, a DNA modification enzyme, and a mobilization element. No differences in colony morphology were observed among the strains. The lack of correlation between PCR patterns and isolation date or collection site is inconsistent with the hypothesis that recent infections are due to the introduction or emergence of novel pathogen strains.
\end{abstract}

Oranges and other citrus fruits are among the most popular fruits in the United States, and California is the major citrus producer for the nation's fresh fruit market (29). California citrus orchards have been affected by citrus stubborn disease (CSD) since 1915 (4). Initially attributed to a viral agent (10), in 1972 the etiologic agent was confirmed as a wall-less bacterium, Spiroplasma citri $(15,31)$. Severely affected trees are stunted and have short leaf internodes, leaf mottling, unseasonal blossoms, and lopsided fruits (4).

S. citri, a phloem-limited mollicute, is transmitted in a circulative-propagative manner by several species of leafhoppers $(21,27)$. The primary vector of $S$. citri in the United States, Circulifer tenellus (Baker), is a polyphagous insect able to transmit the spiroplasma from several weed species commonly found in the foothills of the San Joaquin Valley, CA (3). The general distribution of CSD-infected plants in commercial crops suggests a migration of the infected insects from the weeds to the commercial crops. The ability to feed on different plant species and to migrate long distances make this insect a key element in disease epidemiology (12). Besides C. tenellus, Scaphytopius nitridus (DeLong) also was reported as vector of $S$. citri $(16,27)$ but its importance in CSD epidemiology remains unclear.

Although CSD has been present in the San Joaquin Valley for many years, its impact in the region apparently increased after a series of freezes in California citrus orchards during the 1990s, as more growers reported CSD symptoms. S. citri also was detected for the first time in carrots, first in Washington State (19) and shortly thereafter in California (this paper), possibly reflecting

Corresponding author: J. Fletcher; E-mail address: jacqueline.fletcher@ okstate.edu

doi:10.1094/PHYTO-98-9-0960

(C) 2008 The American Phytopathological Society niche expansion and adaptation of the pathogen to a new plant host.

The very small genome of $S$. citri easily acquires or deletes genetic components, thereby enhancing its fitness (23). For example, continuous graft transmission of $S$. citri from periwinkle to periwinkle resulted in a chromosomal inversion and genomic deletions in S. citri BR3-3X that were associated with loss of transmissibility by the natural vector, $C$. tenellus $(38,40)$. High passage in artificial medium also altered $S$. citri transmissibility (38).

Randomly amplified polymorphic DNA-polymerase chain reaction (RAPD-PCR), using low stringency conditions (22) and random primers having short nucleotide sequences has been used efficiently to discriminate genetic diversity among some plant pathogenic bacteria, including $S$. citri strains (24). Although the reproducibility of RAPD fingerprints can be influenced by the reagents, thermocycler (37) and intensity of amplicons used to score the fingerprint (35), under well-established parameters the results can be very reproducible within a laboratory.

Repetitive element PCR (rep-PCR), which amplifies DNA sequences between repetitive sequences on the bacterial chromosome, also is used to assess genetic diversity in plant pathogenic bacteria (22). The effectiveness of the common rep primers ERIC and BOX, however, apparently is limited in assessing genetic diversity of $S$. citri (25).

The $S$. citri genome has been shown to evolve over relatively short periods of time (23). The possibility that the apparent increase in CSD incidence in California orchards is due to the occurrence of a new $S$. citri strain, led us to compare the genetic diversity among $S$. citri strains recently cultivated from different plant hosts in California (2005 to 2006) with S. citri strains cultivated from various locations between 1980 and 1993. 


\section{MATERIALS AND METHODS}

Bacterial strains and isolation. $S$. citri strains were obtained from various locations and in different years (Tables 1 and 2). Thirty-five strains, collected over the past 25 years from sweet orange (Citrus sinensis [L.] Osb.), grapefruit (Citrus paradisi Macf), horseradish (Armoracia rusticana P. G. Gaertn., B. Mey. \& Scherb), peach (Prunus persica [L.] Batsch), broccoli (Brassica oleracea L.) and the beet leafhopper ( $C$. tenellus), were available in J. Fletcher's collection. Thirty-three additional strains were collected during this study by cultivation from $S$. citri infected sweet orange, carrot (Daucus carota L.), the weed lamb'squarter (Chenopodium album L.), and daikon radish (Raphanus sativus L.) plants from several different locations in the San Joaquin Valley, CA. Sampling occurred during 2005 and 2006 (Table 2, Fig. 1). Two California strains (C189 and S600, Table 2) maintained continuously in planta were obtained from the Citrus Clonal Protection Program (CCPP), University of California, Riverside. A single strain from sweet orange was collected in Israel in 2006. Cultivation was performed using standard procedures in LD8 medium $(2,20)$, and strains were triply cloned and stored at $-80^{\circ} \mathrm{C}$. One to six strains per orchard were cultured and, except for one experiment designed to assess within-tree diversity, each strain was obtained from a different plant. Strains were named, in general, according to site location (1 through 12) and plant (A through F) (Table 2). Strains of S. melliferum, $S$. floricola, S. phoeniceum, and S. kunkelii also were included (Table 1).
DNA isolation. Spiroplasmas were grown in $25 \mathrm{ml}$ of LD8 broth $(20)\left(30^{\circ} \mathrm{C}\right)$ to a titer of $10^{8}$ cells $/ \mathrm{ml}$. Cells were harvested, pellets were resuspended in CTAB buffer, and DNA extraction was accomplished via standard procedures (9). The DNA pellets were dissolved in water and quantified in a spectrophotometer (Nanodrop, ND-1000, Wilmington, DE). The DNA solution was diluted to $4 \mathrm{ng} / \mu \mathrm{l}$ and stored at $-20^{\circ} \mathrm{C}$.

RAPD-PCR and rep-PCR. Twenty 10-oligonucleotide primers, chosen arbitrarily (OPA-09, OPA-18, OPB-01, OPB-16, OPC-03, OPC-13, OPH-08, OPN-11, OPQ-06, OPY-05, OPY-15, OPZ-15, OPAW-05, OPAX-02, OPBF-05, OPAF-07, OPA-13, OPA-14, OPA-15, and OPB-20, Operon Technologies, Alameda, CA), were used in RAPD amplifications. PCR mixtures $(25 \mu \mathrm{l})$ contained $5.7 \mu \mathrm{l}$ of autoclaved distilled water, $2.5 \mu \mathrm{l}$ of GoTaq Flexi buffer (10×) (Promega, Madison, WI), $2.5 \mu \mathrm{l}$ of $\mathrm{MgCl}_{2}(25 \mathrm{mM}), 4 \mu \mathrm{l}$ of dNTP mix (1 mM each) (Fisher Scientific, Fair Lawn, NJ), $20 \mathrm{ng}$ of template, and 1.5 units of GoTaq DNA polymerase (Promega). PCRs without DNA template were used as negative controls. Initial denaturation was performed at $94^{\circ} \mathrm{C}(6 \mathrm{~min})$, followed by 40 cycles of $94^{\circ} \mathrm{C}(1 \mathrm{~min}), 35^{\circ} \mathrm{C}(2 \mathrm{~min}), 72^{\circ} \mathrm{C}(2 \mathrm{~min})$. PTC-200 thermocycler (MJ Research, Inc., Ramsey, MN) was used for all experiments. Rep-PCR conditions were similar, except that the BOX 1AR primer was used (18), and the initial denaturation was $95^{\circ} \mathrm{C}(2 \mathrm{~min})$, followed by 30 cycles of $94^{\circ} \mathrm{C}(3 \mathrm{~s}), 92^{\circ} \mathrm{C}(30 \mathrm{~s})$, $50^{\circ} \mathrm{C}(1 \mathrm{~min})$, and $65^{\circ} \mathrm{C}(8 \mathrm{~min})$. PCR products were electrophoresed in $1.5 \%$ TAE-agarose at $100 \mathrm{~V}$. Bands were compared with a $1 \mathrm{~kb}$ plus DNA ladder (Invitrogen, Carlsbad, CA). Gels were stained with ethidium bromide and visualized using an

TABLE 1. Strains of Spiroplasma citri and other Spiroplasma species analyzed in this study

\begin{tabular}{|c|c|c|c|c|c|}
\hline No. & Strains/species & Geographical origin & Host & Source/(reference) & Isolation date \\
\hline 1 & Ex-Cal & California & Sweet orange & B. Kirkpatrick & 1984 \\
\hline 2 & $\mathrm{O} 1$ & California & Sweet orange & B. Kirkpatrick & 1984 \\
\hline 3 & O-62 & California & Peach & B. Kirkpatrick & 1984 \\
\hline 4 & O-202 & California & Peach & B. Kirkpatrick & 1984 \\
\hline 5 & O-15 & California & Broccoli & B. Kirkpatrick & 1984 \\
\hline 6 & B105 & California & Sweet orange & R. Whitcomb & 1983 \\
\hline 7 & B106 & California & Sweet orange & R. Whitcomb & 1983 \\
\hline 8 & CB1 & California & Leafhopper & R. Whitcomb (5) & 1983 \\
\hline 9 & GO-3 & Coachella Valley, California & Grapefruit & G. Oldfield (isolated by J. Fletcher) & 1993 \\
\hline 10 & GO-5 & Coachella Valley, California & Grapefruit & G. Oldfield (isolated by J. Fletcher) & 1993 \\
\hline 11 & BR1 & Illinois & Horseradish & J. Fletcher (13) & 1980 \\
\hline 12 & BR6 & Illinois & Horseradish & J. Fletcher (13) & 1980 \\
\hline 13 & BR11 & Illinois & Horseradish & J. Fletcher & 1984 \\
\hline 14 & BR 12 & Illinois & Horseradish & J. Fletcher & 1984 \\
\hline 15 & BR 14 & Illinois & Horseradish & J. Fletcher & 1984 \\
\hline 16 & BR 15 & Illinois & Horseradish & J. Fletcher & 1984 \\
\hline 17 & BR 17 & Illinois & Horseradish & J. Fletcher & 1984 \\
\hline 18 & BR 18 & Illinois & Horseradish & J. Fletcher & 1984 \\
\hline 19 & BR3 & Illinois & Horseradish & J. Fletcher (13) & 1980 \\
\hline 20 & BR3G & Derived from BR3 & Horseradish & J. Fletcher (38) & $\mathrm{NA}^{\mathrm{a}}$ \\
\hline 21 & BR3T & Derived from BR3 & Horseradish & J. Fletcher (38) & NA \\
\hline 22 & BR3-42 & Derived from BR3 & Horseradish & J. Fletcher (38) & NA \\
\hline 23 & BR3-80 & Derived from BR3 & Horseradish & J. Fletcher (38) & NA \\
\hline 24 & BR3P & Derived from BR3 & Horseradish & J. Fletcher (38) & NA \\
\hline 25 & MDHR2 & Charles County, Maryland & Horseradish & R. Davis (7) & 1981 \\
\hline 26 & MDHR4 & Charles County, Maryland & Horseradish & R. Davis (7) & 1981 \\
\hline 27 & MDHR5 & Charles County, Maryland & Horseradish & R. Davis (7) & 1981 \\
\hline 28 & $\mathrm{M} 200 \mathrm{H}$ & Derived from R8A2 & Sweet orange & R. Davis (34) & NA \\
\hline 29 & M200HX & Derived from R8A2 & Sweet orange & R. Davis (34) & NA \\
\hline 30 & MR3 & Derived from R8A2 & Sweet orange & R. Davis (34) & NA \\
\hline 31 & $\mathrm{R} 8 \mathrm{~A} 2$ & Morocco & Sweet orange & R. Davis (31) & 1985 \\
\hline 32 & Beni-Mellal & Morocco & Sweet orange & S. Purcell & 1984 \\
\hline 33 & Maroc & Morocco & Sweet orange & R. Whitcomb & 1983 \\
\hline 34 & Iran & Iran & Sweet orange & R. Whitcomb & 1983 \\
\hline 35 & ASP-1 & Israel & Sweet orange & R. Davis (36) & 1981 \\
\hline 36 & Spiroplasma melliferum/TS-2 & Maryland & Honey bee & R. Davis (5) & 1991 \\
\hline 37 & Spiroplasma phoeniceum & Middle East & Periwinkle & R. Davis & 1982 \\
\hline 38 & Spiroplasma floricola/23-6 & Maryland & Tulip tree & R. Davis (6) & 1978 \\
\hline 39 & Spiroplasma kunkelii/CR2 & Alajuela, Costa Rica & Corn & J. Fletcher & 1987 \\
\hline
\end{tabular}

a NA, does not apply. 
AlphaImager and Alphaease FC software (Alpha Innotech Corporation, San Leandro, CA).

Patterns of RAPD and rep-PCR DNA fingerprints were assessed visually. The presence or absence of bands in each strain was transformed into binary data (presence $=1$, absence $=0$ ) using an Excel (Microsoft) processor and the data saved as a text file. Data reliability was assessed using SEQBOOT (PHYLIP) (11), followed by the MIX parsimony program (PHYLIP) (11). Consensus trees (Consense, PHYLIP) were generated using S. floricola as outgroup. The tree was visualized in the TREEVIEW program (28). Complementary binary data were analyzed using the SAS/PRINCOMP procedure, SAS software 9.1 (33).

Within-tree $S$. citri genetic variability. To assess within-tree spiroplasma variability, three infected sweet orange trees from each of two orchards (orchards 4 and 5, Fig. 1) were selected randomly. On 17 May 2006, one fruit was harvested from each of four different locations within each tree (total of four fruits per tree), and spiroplasmas were cultured in LD8 broth from columella tissue $(2,20)$. Initial culture filtrates were diluted and subcultured on agar-solidified LD8 medium; seven to eight different individual colonies per tree were increased in liquid LD8 broth. DNA extraction and RAPD-PCR were performed as described above using primers OPA-09, OPY-05, OPC-13, and OPB-20, which had previously proved useful to differentiate strains.

Sequencing of differential bands. Five differential amplicons were extracted from agarose gels and purified with a Geneclean Turbo Kit (Qbiogene, Inc., Carlsbad, CA). DNA was cloned in Escherichia coli (strain Mach $1-\mathrm{T}^{\mathrm{R}}$ ) using the Topo TA Cloning Kit (Invitrogen, Carlsbad, CA). Plasmids from successfully transformed clones were extracted by a small-scale preparation alkaline lysis and cleaned with choloroform:phenol separation, and dissolved in water (32). The target inserts were confirmed by restriction digests with EcoRI according to product specifications (Promega). Sequencing was performed using standard methods in an automated 3730 DNA analyzer (Applied Biosystems, Foster City, CA). Sequences were compared by nucleotide blast and submitted to NCBI data base (1).

S. citri colony morphology in LD8 medium. To assess whether genetic diversity was related to $S$. citri colony morphology, two historical (strains 19 and 35, Table 1) and nine recently collected S. citri strains (strains 40, 41, 47, 54, 56, 63, 68, 73, and 74, Table 2) were selected for further study.

Twenty-four hour old cultures of $S$. citri strains were diluted in PBS buffer and plated on LD8 agar (0.6 or $1.0 \%$ noble agar). Colony morphology was evaluated after 10 or 30 days of incubation at $30^{\circ} \mathrm{C}$ in the dark. Dienes' stained (8) plates were observed using stereo and light microscopy. Images were acquired in bright field using an Olympus BX51 microscope (Olympus Optical Co., Tokyo, Japan). From strains that yielded more than one type of colony, single cells were subcultured in LD8 medium to assess the stability of the colony morphology. This experiment was repeated two times.

\section{RESULTS}

RAPD-PCR and rep-BOX. All 20 RAPD primers yielded differential amplification patterns among the five spiroplasma species evaluated, and 17 did so among S. citri strains. Patterns

TABLE 2. Spiroplasma citri strains cultivated in 2005 and 2006 and analyzed in this study

\begin{tabular}{|c|c|c|c|c|c|c|c|}
\hline \multirow[b]{2}{*}{ No. } & \multirow[b]{2}{*}{ Site $^{\mathrm{a}}$} & \multicolumn{2}{|c|}{ Strains } & \multirow[b]{2}{*}{ Origin } & \multirow[b]{2}{*}{ Host } & \multirow[b]{2}{*}{ Source/reference } & \multirow[b]{2}{*}{ Isolation } \\
\hline & & This paper designation & Original designation & & & & \\
\hline 40 & 11 & $\mathrm{C} 5$ & $\mathrm{C} 5$ & Kern County, California & Carrot & This study & 2005 \\
\hline 41 & 11 & $\mathrm{C} 17$ & $\mathrm{C} 17$ & Kern County, California & Carrot & This study & 2005 \\
\hline 42 & 2 & $2 \mathrm{~A}$ & $\mathrm{Ca} 1$ & Tulare County, California & Sweet orange & This study & 2005 \\
\hline 43 & 3 & $3 \mathrm{~A}$ & $\mathrm{Ca} 7$ & Tulare County, California & Sweet orange & This study & 2005 \\
\hline 44 & 3 & 3B & Ca 12 & Tulare County, California & Sweet orange & This study & 2005 \\
\hline 45 & 3 & $3 \mathrm{C}$ & Ca 16 & Tulare County, California & Sweet orange & This study & 2005 \\
\hline 46 & 3 & $3 \mathrm{D}$ & Ca 20 & Tulare County, California & Sweet orange & This study & 2005 \\
\hline 47 & 3 & $3 \mathrm{E}$ & $\mathrm{Ca} 23$ & Tulare County, California & Sweet orange & This study & 2005 \\
\hline 48 & 3 & $3 \mathrm{~F}$ & $\mathrm{Ca} 28$ & Tulare County, California & Sweet orange & This study & 2005 \\
\hline 49 & 6 & $6 \mathrm{~A}$ & Ca 35 & Kern County, California & Sweet orange & This study & 2005 \\
\hline 50 & 6 & $6 \mathrm{~B}$ & $\mathrm{Ca} 40$ & Kern County, California & Sweet orange & This study & 2005 \\
\hline 51 & 6 & $6 \mathrm{C}$ & $\mathrm{Ca} 42$ & Kern County, California & Sweet orange & This study & 2005 \\
\hline 52 & 6 & $6 \mathrm{D}$ & $\mathrm{Ca} 46$ & Kern County, California & Sweet orange & This study & 2005 \\
\hline 53 & 6 & $6 \mathrm{E}$ & Ca 51 & Kern County, California & Sweet orange & This study & 2005 \\
\hline 54 & 6 & $6 \mathrm{~F}$ & Ca 53 & Kern County, California & Sweet orange & This study & 2005 \\
\hline 55 & 4 & $4 \mathrm{~A}$ & $\mathrm{Ca} 62$ & Kern County, California & Sweet orange & This study & 2005 \\
\hline 56 & $\mathrm{NA}^{\mathrm{b}}$ & Ir & Israel & Bet-Dagan, Israel & Sweet orange & This study & 2006 \\
\hline 57 & 1 & Dk & $\mathrm{Ca} 264$ & Fresno County, California & Daikon radish & This study & 2005 \\
\hline 58 & 4 & $4 \mathrm{~B}$ & $\mathrm{Ca} 204$ & Kern County, California & Sweet orange & This study & 2006 \\
\hline 59 & 4 & $4 \mathrm{C}$ & Ca 198 & Kern County, California & Sweet orange & This study & 2006 \\
\hline 60 & 4 & $4 \mathrm{D}$ & Ca 207 & Kern County, California & Sweet orange & This study & 2006 \\
\hline 61 & 5 & $5 \mathrm{~A}$ & $\mathrm{Ca} 160$ & Kern County, California & Sweet orange & This study & 2005 \\
\hline 62 & 5 & $5 \mathrm{~B}$ & $\mathrm{Ca} 242$ & Kern County, California & Sweet orange & This study & 2006 \\
\hline 63 & 5 & $5 \mathrm{C}$ & $\mathrm{Ca} 256$ & Kern County, California & Sweet orange & This study & 2006 \\
\hline 64 & NA & C189 & C189 & $\mathrm{CCPP}^{\mathrm{c}}$ & Sweet orange & CCPP (15) & 2006 \\
\hline 65 & NA & $600 \mathrm{~B}$ & $600 \mathrm{~B}$ & CCPP & Sweet orange & CCPP & 2006 \\
\hline 66 & 9 & W & $\mathrm{Ca} 263$ & Fresno County, California & Lamb's-quarter & This study & 2006 \\
\hline 67 & 7 & $7 \mathrm{~A}$ & $\mathrm{Ca} 144$ & Kern County, California & Sweet orange & This study & 2005 \\
\hline 68 & 8 & $8 \mathrm{~A}$ & $\mathrm{Ca} 170$ & Fresno County, California & Sweet orange & This study & 2006 \\
\hline 69 & 12 & $\mathrm{C} 1$ & C1 & Kern County, California & Carrot & This study & 2006 \\
\hline 70 & 12 & $\mathrm{C} 3$ & $\mathrm{C} 3$ & Kern County, California & Carrot & This study & 2006 \\
\hline 71 & 12 & C6 & C6 & Kern County, California & Carrot & This study & 2006 \\
\hline 72 & 12 & $\mathrm{C} 7$ & $\mathrm{C} 7$ & Kern County, California & Carrot & This study & 2006 \\
\hline 73 & 12 & $\mathrm{C} 8$ & $\mathrm{C} 8$ & Kern County, California & Carrot & This study & 2006 \\
\hline 74 & 10 & SL & SL & Kern County, California & Sweet orange & This study & 2006 \\
\hline
\end{tabular}

${ }^{a}$ See map (Fig. 1).

${ }^{\mathrm{b}}$ NA, does not apply.

c CCPP, Citrus Clonal Protection Program, University of California, Riverside. 
that revealed the greatest diversity among strains are presented (Figs. 2 and 3). The 159 differential RAPD amplicons ranged from 3.0 to $0.25 \mathrm{kbp}$ in size. No consistent differences were observed between new strains of $S$. citri collected in this study and strains cultured from up to 27 years ago ("historic" strains) (Fig. 2). Most of the amplicon patterns observed from new strains of $S$. citri varied from site to site of geographical origin; however, a few correlated consistently with the site of collection (Fig. 2B, arrow). Some fragments from carrot (Fig. 3A, arrow) or daikon radish (Fig. 3B, star) strains were not amplified from citrus strains. Banding profiles produced by BOX-PCR were indistinguishable among the strains (data not shown).

Transformed binary data from the RAPDs was used to generate a phylogenetic tree (Fig. 4) in which S. floricola, S. phoeniceum, $S$. kunkelii, and $S$. melliferum formed four separate branches. $S$. citri strains fell into two major clusters, both containing mixtures of historic and new strains. One cluster included new strains from sweet orange orchards 2, 4, 5, and 8, a new strain from Israel, and carrot strains from two different California sites. The other cluster included new strains from sweet orange orchards $3,6,7,10$, and from the lamb's-quarter, collection site 9 (Fig. 4).

Spiroplasma strains from carrot were all highly similar to one another and most clustered together (Fig. 4). In contrast, sweet orange strains newly cultured from 8 different groves were widely distributed in the two main brackets of the dendrogram (Fig. 4). Although orchards 3, 4, 5, and SL were adjacent to one another along the Sierra Mountain foothills in Kern County, CA, high variability in RAPD patterns resulted in the placement of strains from these orchards into two separate clusters (Fig. 4). Moreover, significant genetic diversity among spiroplasmas from orchards 4 and 5 was observed; these strains clustered more loosely than did strains from orchards 3 and 6 , which were highly similar to one another (Fig. 4).

Both historic and new strains of $S$. citri were distributed widely among branches of the phylogenetic tree, presenting little evidence of correlation between clustering and date of isolation (Fig. 4). Exceptions were strains R8A2, Maroc, MR3, M200HX, and $\mathrm{M} 200 \mathrm{H}$, all of which are from the same geographical region; in fact, the latter three are laboratory derivatives of the first (34). Interestingly, strain BR3, the progenitor of BR3-42, BR3-80, BR3-P, BR3-T, and BR3-G, clustered closely only with BR3-42, which was derived from BR3 by 42 successive subcultures (14). It was somewhat removed from BR3-80 and BR3-P, which were derived from it by 80 or 130 successive subcultures, respectively (38), and from BR3-T and BR3-G, which were derived from it by successive transmission by beet leafhoppers or periwinkle grafting, respectively (38). In addition, S. citri strains BR15, BR17, and BR18, from adjacent horseradish field sites in Illinois, also showed significant genetic diversity (Fig. 4).

Principal component analysis (PCA) of S. citri historic and new strains showed that the first two principal components explained $30.3 \%$ of the variation encountered in the analysis. Primers OPA15 , OPA-18, and OPN11 appeared to have a great influence on the first two components. In agreement with the phylogenetic tree, there was no clustering between historic and new strains (Fig. 5A). PCA of S. citri strains cultivated from orchards 3 to 6 showed that in some orchards the genetic variability within a grove was very limited and in others the genetic variability within groves was greater (Fig. 5B).

Within-tree genetic diversity. $S$. citri genetic diversity within single sweet orange trees in orchards 4 and 5 was evidenced by differential banding patterns obtained using primers OPA-09 and OPC-13. In orchard 4, only one of the three sweet orange trees evaluated yielded multiple genotypes (data not shown). In orchard 5 , two of the three plants evaluated were infected by more than one type of spiroplasma in the same plant. One of the trees yielded two, and the other tree yielded three, different RAPD patterns (Fig. 6).
Sequencing of differential amplicons. Sequencing of five RAPD amplicons that were produced differentially among strains (diversity-related gene sequences) identified two plectroviral fragments and fragments potentially encoding parts of a membrane lipoprotein, a DNA modification enzyme, and a mobilization element (Table 3).

S. citri colony morphology. Of the $11 \mathrm{~S}$. citri strains plated onto solid medium, only strain 35 (ASP-1) presented a stable colony morphology in both experiments performed, independent of the agar concentration used; its colonies were of the "fried egg" type (colony type B, Fig. 7). All other strains produced some colonies with fried egg morphology and others having a dense center surrounded by satellite colonies (colony type A, Fig. 7). When colonies of either type were picked, subcultured in LD8 broth medium and re-plated, they again yielded colonies of both types (Fig. 7).

\section{DISCUSSION}

Genetic diversity in bacteria can be assessed by examining specific restriction sites, repetitive elements, genome sequences, or the amplicons produced by random primers (RAPD) (22). RAPD-PCR, when optimized for a particular application, provides effective discrimination among species and strains (30). RAPD primers used in the present study were suitable for differentiating $S$. citri from other members of spiroplasma serogroup I (S. melliferum, S. kunkelii, and S. phoeniceum) and serogroup III (S. floricola) and also for discriminating genetic differences among $S$. citri strains.

Significant genetic variability of $S$. citri apparently has existed in California, Maryland, and Illinois for a long period of time. Strains obtained in 1993 (GO3 and GO5) from two grapefruit trees in the same Coachella Valley, CA, orchard and located only

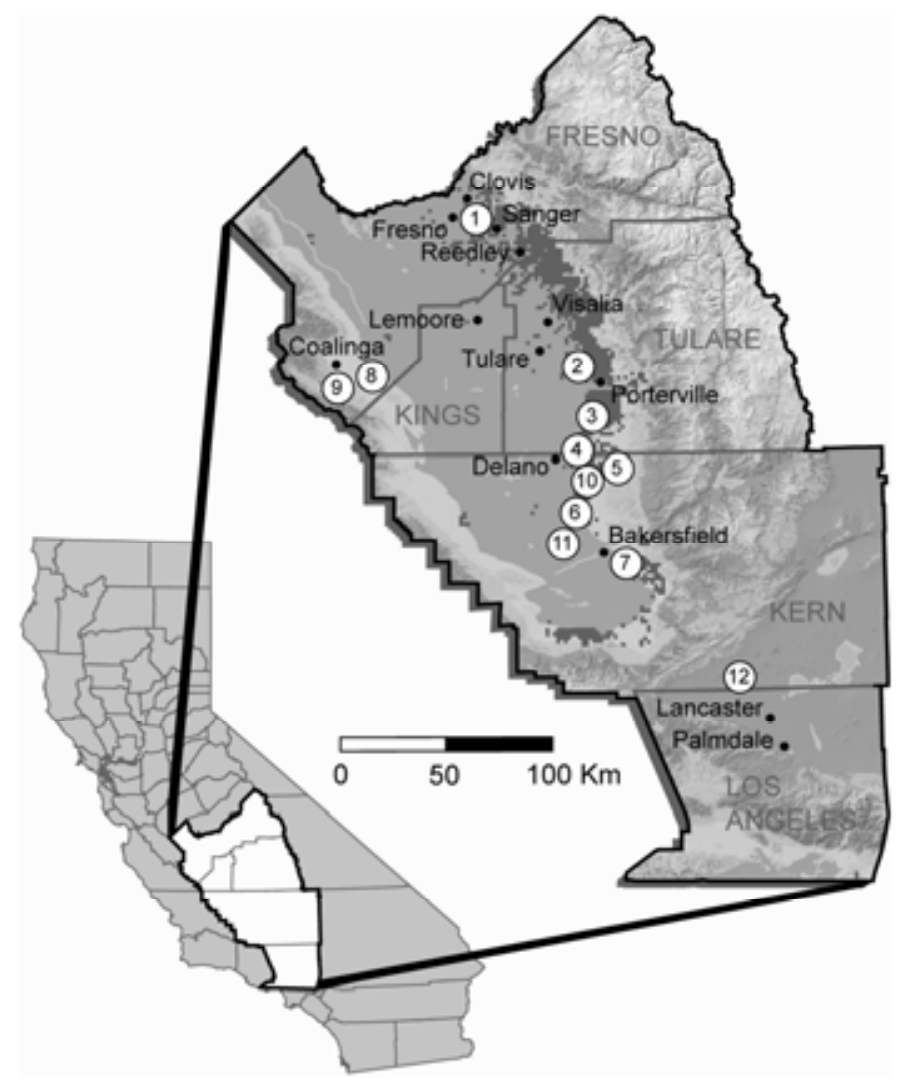

Fig. 1. Location of citrus orchards and other sites in the San Joaquin and Antelope Valleys, CA where Spiroplasma citri was collected for this study. Each gray square represents $1.61 \mathrm{~km}^{2}$ in which a commercial orchard of 25 or more citrus trees was planted. 
two trees apart, yielded so many differential amplicons that these strains were separated into the two main branches of the phylogenetic tree. The same phenomenon was observed with some $S$. citri strains cultivated from 1981 to 1984 from horseradish plants with symptoms of brittle root disease from adjacent fields in Illinois or Maryland $(7,13)$. Yokomi et al. (41) have shown the presence of two genetically different populations of $S$. citri in field trees from central California and from historical strains collected from southern California in the 1960s.

It is challenging to evaluate the significance of the differences among strains and clusters in the RAPD-PCR generated phylogenetic tree of Figure 4. One measure of significance can be generated by examining two cases in which several different $S$. citri lines, derived from a common parent strain under laboratory conditions, generated different RAPD patterns in the present work. Such comparisons are useful because, since we know the deriva- tion histories and some of the genomic information about these strains, we can apply that information to inform our interpretation of the RAPD results in this study. In one example, strain BR3, which was cultivated originally from $S$. citri-infected Illinois horseradish, generated derivative genotypes after successive subculturing in vitro or after extended cycles of either leafhopper transmission or plant graft transmission (14). Previous work revealed differences in protein profiles of the nontransmissible BR3-derivative lines BR3-P and BR3-G, obtained by in vitro and graft transmission, in comparison with BR3, the parent line, and with BR3-T, a still-transmissible leafhopper-transmitted derivative (14). In addition, BR3-G had sustained a chromosomal inversion and two deletions compared with its progenitor (40), mutations that likely were involved in its loss of transmissibility. In the lineage proposed by our RAPD analysis (Fig. 4), BR3 and BR3-T are each more closely aligned with other $S$. citri strains than to
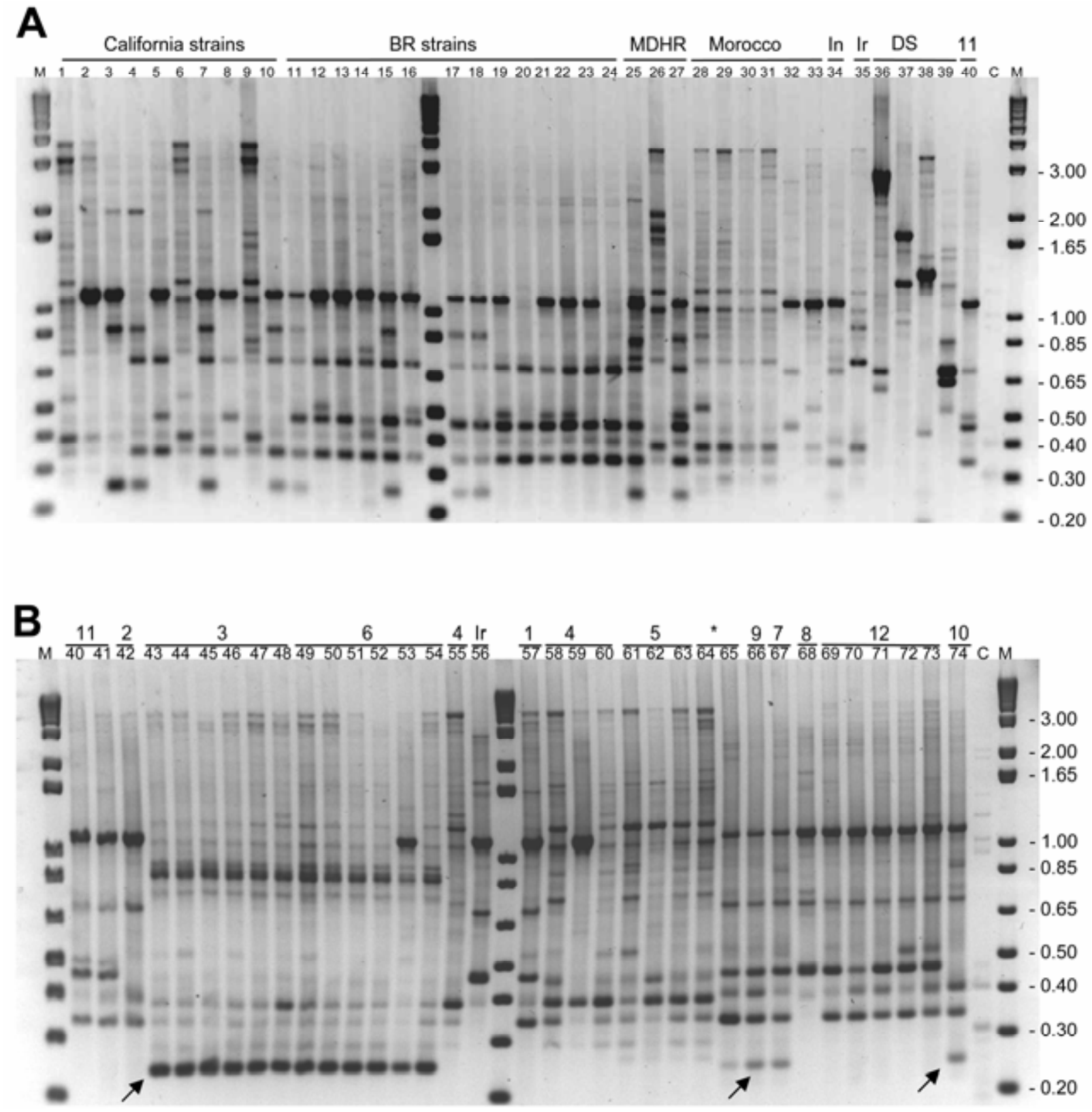

Fig. 2. Random amplified polymorphism DNA (RAPD) fingerprints generated using primer OPA-15 and a template of historic (A) or new strains (B) from California and Israel. Numbers below bars indicate strain; lanes C: the control reaction without template DNA, lanes M: DNA ladder $1 \mathrm{~kb}$ plus; size fragments are listed on the right. Above the bar: A, Historic strains: 1 to 10, from California; 11 to 24, from Illinois horseradish; 25 to 27, from Maryland horseradish; 28 to 33, from Morocco; 34 and 35, from Iran (In) and Israel (Ir); 36 to 39, different species of spiroplasma (DS), and 40, new strain from site 11. B, New strains: site 1, daikon radish; sites 2 to 8 and 10, citrus orchards; site 9, lamb's-quarter; and sites 11 and 12, carrot. Asterisk indicates strains cultivated from grafted plants from the Citrus Clonal Protection Program; and Ir, new strain from Israel. Arrows indicate Spiroplasma citri amplicon specific to some citrus sites and to lamb's-quarter. 
each other. In a second example, RAPD pattern differences were observed among strains M200H, M200HX, and MR3, all of which are subculture derivatives of strain R8A2. MR3 is able to resist infection by a spiroplasma virus isolated from $S$. melliferum, unlike its parent, which remains susceptible (34). Consideration of the phylogenetic tree clusters in tandem with previous knowledge of the same strains provides a sense of the scale of the differences identified in this study.

Despite the great variability in RAPD profiles encountered among the $70 \mathrm{~S}$. citri strains evaluated in this study, no particular pattern differentiates $S$. citri strains collected between 2005 and 2006 from strains collected between 1980 and 1993. Comparison among strains recently collected from California orchards showed that genetic patterns of $S$. citri within an orchard could be similar or very different. Since the majority of the orchards sampled were located near the foothills in the east side of the Central Valley, the different degrees of genetic diversity may reflect greater or lesser exposure of the trees to insect vectors, and, consequently, more or fewer inoculation events. Genetic homogeneity in some groves could also be consequence of dispersion by nursery propagation. One RAPD primer (OPA-13) differentiated between carrot and citrus strains of $S$. citri. This result is different from an earlier report that showed no significant genetic differences among citrus and carrot strains. However, since the first study used the $16 \mathrm{~S}$ rDNA region that is used primarily as a bacterial taxonomic tool these RAPD results are not comparable (19).

The $S$. citri genome is one of the largest among Mollicutes, and is characterized by high adenosine-thymidine content. In addition to its circular chromosome, S. citri also harbors plasmids and virus genomes, which likely serve as sources of genetic information $(23,39)$. Genetic variations of spiroplasmas are attributed to DNA acquisition and loss, DNA replication and repair, homologous recombination and transposition (23). Amplicons sequenced in the present work showed that, in addition to the fact that bacteriophages occupy a considerable proportion of the $S$. citri genome, genetic differences among strains may result from several different mechanisms within the genome. Such inserts included a hypothetical gene for a DNA methyltransferase, an enzyme associated with DNA protection and repair, a transmembrane lipoprotein which the C-terminal is also virtually identical to SpV1-R8A2 B phage ORF product and a mobilization-like protein.

S. citri cells usually are motile and helical when cultured on LD8 medium, and move linearly in medium solidified with a low
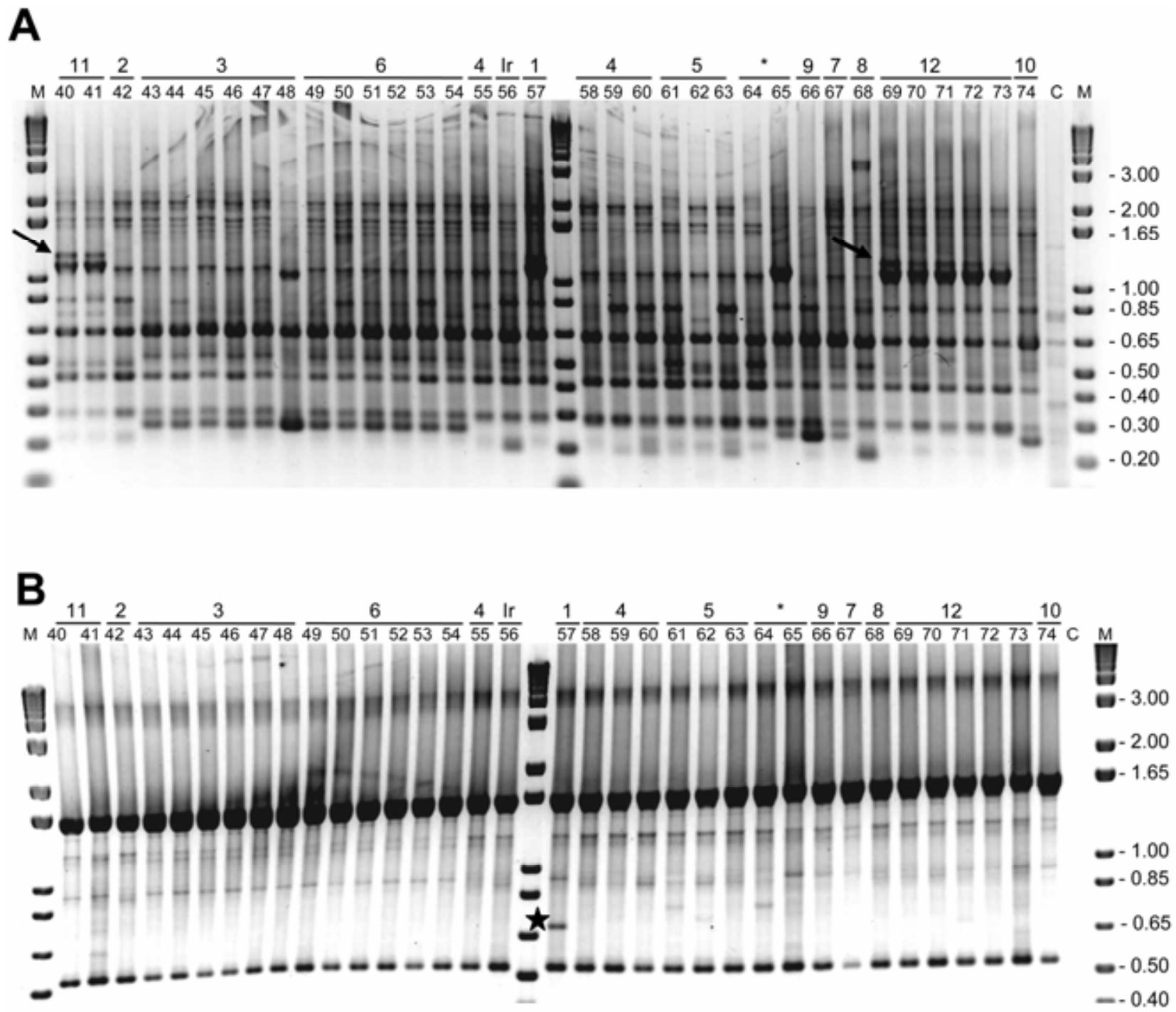

Fig. 3. Random amplified polymorphism DNA fingerprints after amplification with primers A, OPA-13 and B, OPZ-15; template DNA from new strains from California and Israel. Numbers below the bar show strain identification; lanes C: the control reaction without template DNA; lanes M: DNA ladder $1 \mathrm{~kb}$ plus, size fragments on right. Above the bar: site 1, daikon radish; sites 2 to 8 and 10, citrus orchards; site 9, lamb's-quarter; sites 11 and 12, carrot; Asterisk indicates strains cultivated from grafted plants obtained from Citrus Clonal Protection Program; and Ir, new strain from Israel. Arrows indicate a specific amplicon in carrots (40, 41 and 69 to 73) (A) and the star indicates a specific amplicon in daikon radish (57) (B). 
agar concentration, forming colonies with indistinct edges due to the formation of satellite colonies. Strains having low motility in agar medium yield colonies with well-defined edges, sometimes called "fried-egg" colonies. These colony types have been found in natural populations from CSD citrus trees in the Middle East (36), and also in motility-impaired mutants generated by $\mathrm{Tn} 4001$ transposition (17). In our study, except for S. citri ASP-1, previously reported as a nonhelical, nonmotile, fried-egg colonyproducing strain, none of the spiroplasma strains maintained a single stable colony morphology during successive subculturing. Colony morphology apparently is unreliable as a means of differentiating strains. Whether such variation is related to the phenomenon of phase variation, in which a variety of molecular mechanisms in mollicutes give rise to variable phenotypes (26), is not known.

S. citri genetic diversity within single trees in citrus orchards 4 and 5 showed that, under conditions of commercial citrus orchards, populations of $S$. citri may be heterogeneous. The explanation for

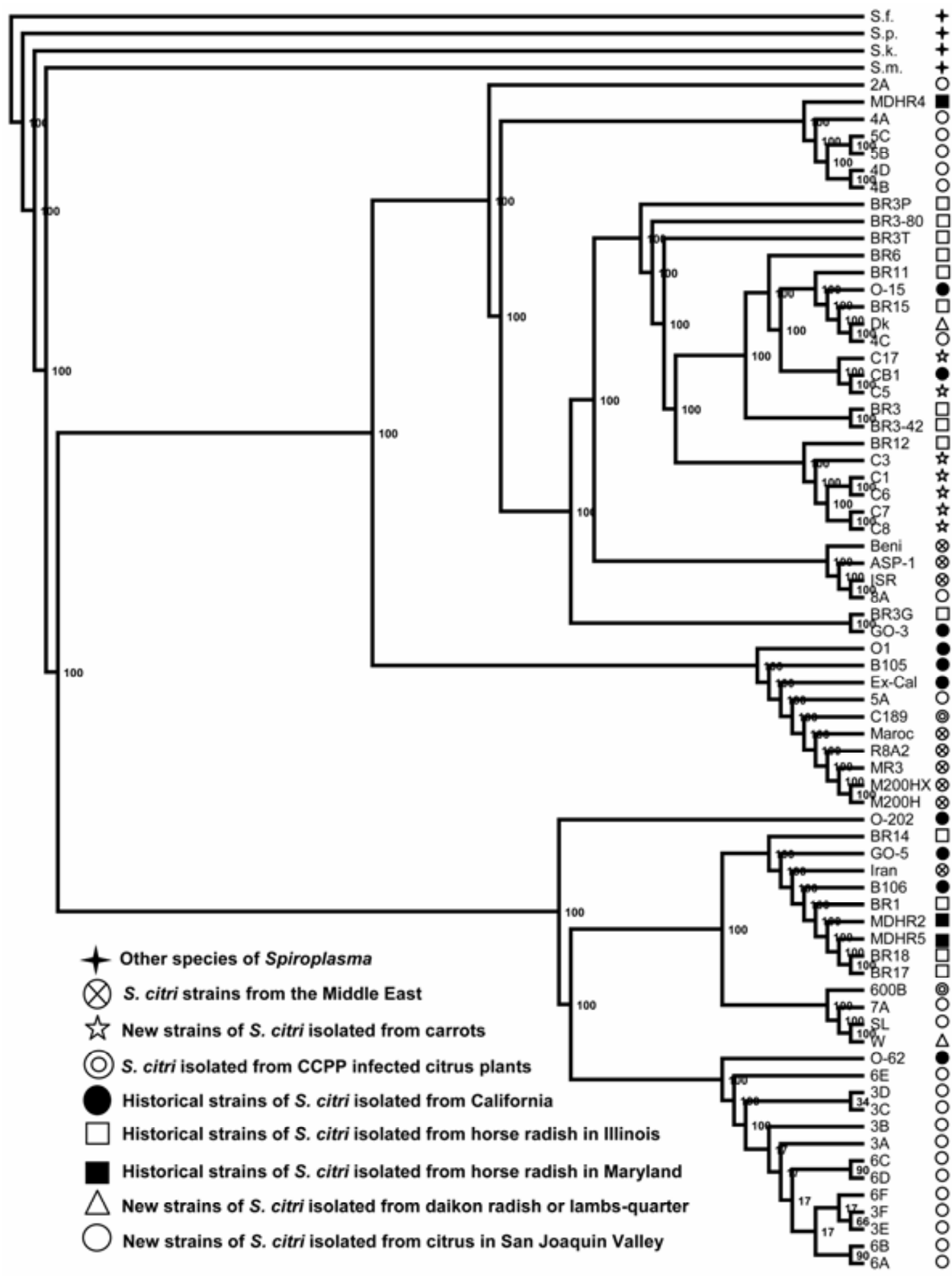

Fig. 4. A phylogenetic tree constructed by mix parsimony (PHYLIP) based on the 159 characters of the 70 different strains of Spiroplasma citri and of S. melliferum (S.m), S. floricola (S.f.), S. phoeniceum (S.p.), and S. kunkelii (S.k). Numbers at the nodes indicate the levels of bootstrap support (percentage) based on 1,000 repetitions for the branches immediately to the left. 

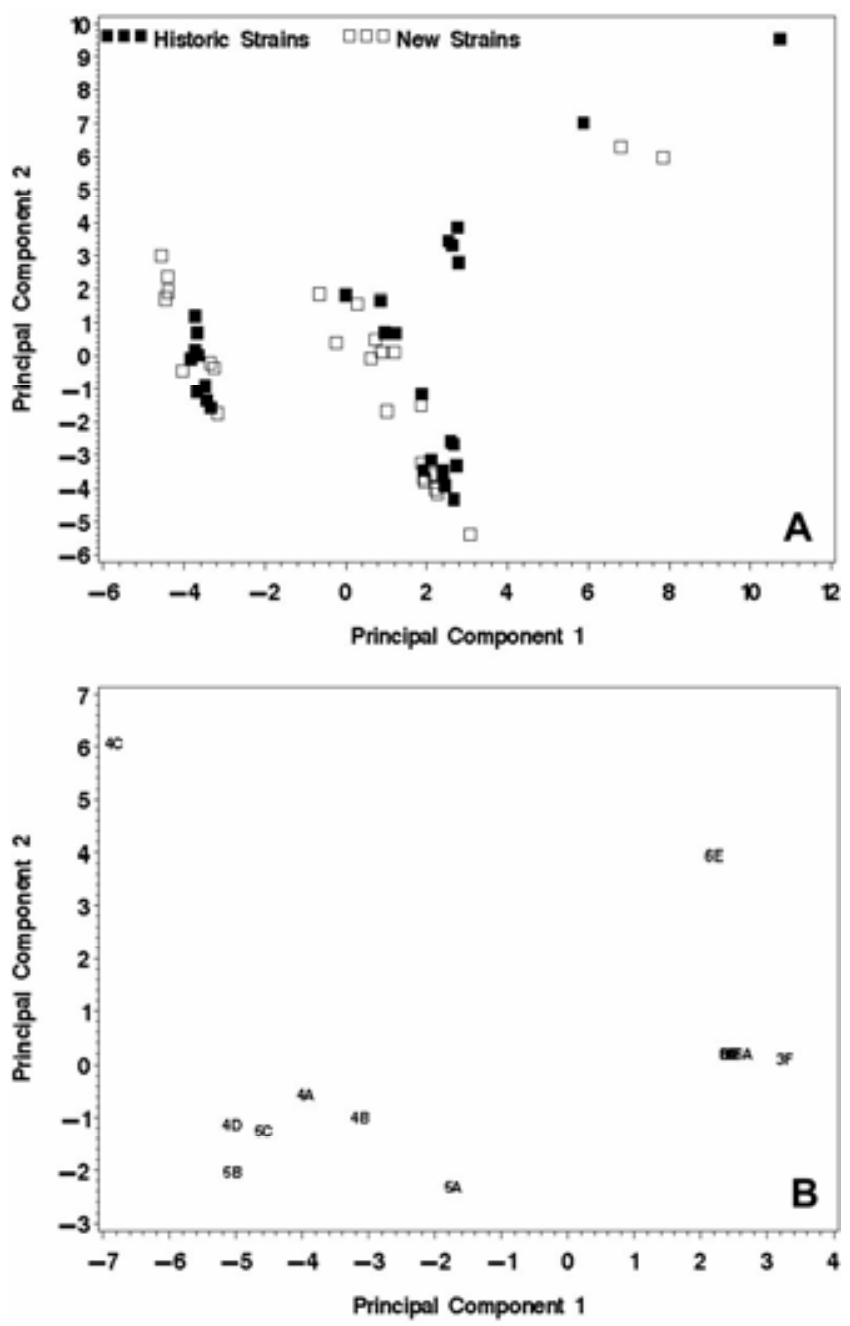

Fig. 5. Arrangement of Spiroplasma citri strains based on principal component analysis using as input the differential characters obtained in random amplified polymorphism DNA reactions. A, Analysis including historic S. citri strains (black squares) and new strains (open squares). B, S. citri isolates from orchards (sites) 3 to 6 . Majority of strains from orchards 3 and 6 formed a tight cluster at principal coordinate 1 (3) and principal coordinate 2 (0). such diversity could be multiple natural infections of single trees by heterogeneous strains, a series of in planta genetic alterations, or grafting of young rootstocks with mixtures of field-infected and nursery-contaminated bud-wood.

The lack of major differences among historic and new strains leads us to conclude that genetic changes in S. citri genome were not a significant factor in any reemergence of CSD in California orchards. The epidemiology of CSD is complex. The pathogen infects several plant host species including commercial crops and weeds, and has several different leafhopper vectors, all of which could influence the impact of CSD in California.

\section{ACKNOWLEDGMENTS}

We thank E. Civerolo, M. Pierce, and S. Marek for reviewing the manuscript; L. Whitworth of the Recombinant DNA/Protein Resource Facility of Oklahoma State University for assistance in amplicon sequencing; J. Nunez for providing carrot samples; California citrus growers

TABLE 3. Description and putative functions of sequences of strain-differential amplicons of Spiroplasma citri obtained by random amplified polymorphism DNA-polymerase chain reaction

\begin{tabular}{lccl}
\hline $\begin{array}{l}\text { Strain } \\
\text { sequenced }\end{array}$ & $\begin{array}{c}\text { Amplicon } \\
\text { size (bp) }\end{array}$ & $\begin{array}{c}\text { Accession } \\
\text { number }\end{array}$ & \multicolumn{1}{c}{ Function/product } \\
\hline $35^{\mathrm{a}}$ & 520 & EU005544 & Plectrovirus Spv1-c74 \\
$68^{\mathrm{b}}$ & 176 & EU005545 & $\begin{array}{l}\text { Plectrovirus Spv1-R8A2b } \\
43^{\mathrm{c}}\end{array}$ \\
& 227 & EU005546 & $\begin{array}{c}\text { Hypothetical lipoprotein } \\
\text { transmembrane }\end{array}$ \\
$40^{\mathrm{d}}$ & 1186 & EU005547 & $\begin{array}{l}\text { MOB-like protein } \\
\text { Hypothetical DNA methyltrans- } \\
63^{\mathrm{e}}\end{array}$ \\
& 688 & EU005548 & \begin{tabular}{l} 
ferase protein \\
\hline
\end{tabular} \\
\hline
\end{tabular}

a Amplicon unique to historic strains 19, 22, 24, 34, and 35; the new Israeli strain 56; and a new strain from site 8 in California, 68, using primer OPA09.

b Amplicon present in new strains 40 to 42, 57 to 63, 66, and 68; and historic strain 35 , using primer OPA-13.

${ }^{c}$ Amplicon present only in trees from sites 3, 6, 7, and 9 (new strains 43 to 54 and 65 to 67 ) and in historic strains $3,7,10,11,15,17,18,25$, and 27, using primer OPA-13.

d Amplicon present only in carrot strains 40, 41, and 69 to 73, daikon radish strain 57 , and historic strains $5,8,11$ to 14,16 to 19,21 to 24 , and 26 , using primer OPA-13.

e Amplicon present in some, but not all, trees of site 6, using primer OPC-13.

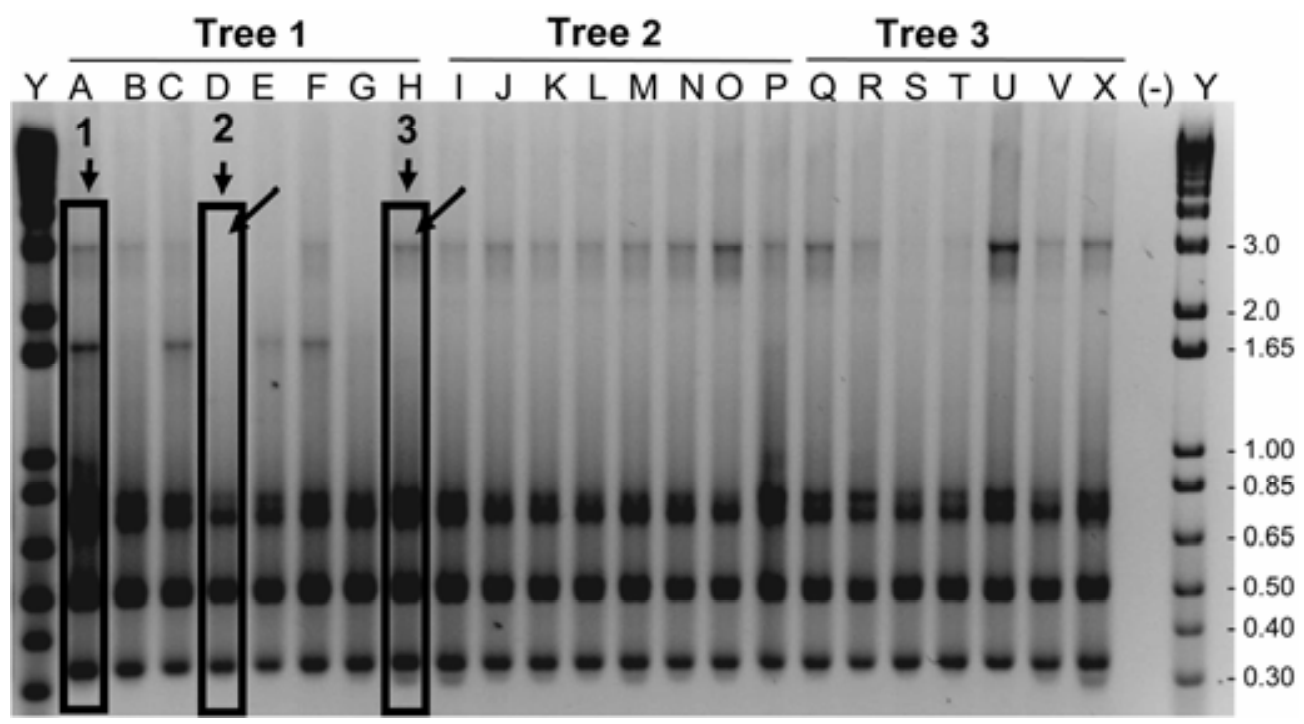

Fig. 6. Random amplified polymorphism DNA fingerprints after amplification with primer OPA-09. DNA extracted from 7 to 8 Spiroplasma citri strains, selected by single-cell cloning from multiple fruits from three different sweet orange trees in orchard 5, served as template. Above the bar: tree identification; below the bar: strain identification; tree 1, strains A to $\mathrm{H}$; tree 2, strains I to P; tree 3, strains Q to X and the control reaction without template DNA (-). Lane Y: DNA ladder $1 \mathrm{~kb}$ plus, size fragments listed on right. Arrows indicate differential patterns: 1 , presence of 3.0 and $1.65 \mathrm{kbp}$ amplicons; 2 , absence of 3.0 and $1.65 \mathrm{kbp}$ amplicons; and 3, presence of $3.0 \mathrm{kbp}$ and absence of $1.65 \mathrm{kbp}$ amplicons. 


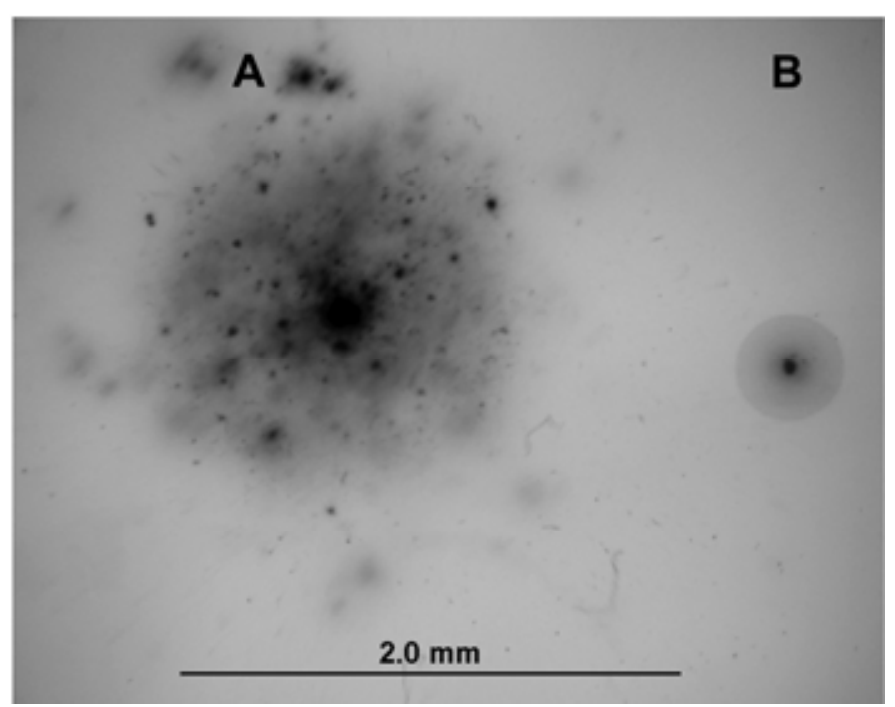

Fig. 7. Mixed colony types of Spiroplasma citri obtained from strain 41, cultivated from infected carrot plants on agar-solidified $(0.6 \%)$ LD8 medium. A, colony with satellites and $\mathbf{B}$, fried egg colony.

for allowing us to sample their orchards; G. Tanaka (www.valleymapping.com) for preparing the map of sites used to sample $S$. citri; and C. Goad for assistance with statistical evaluations. This study was funded by United States Department of Agriculture-Agricultural Research Service project number 5302-22000-009-00 and by the Oklahoma Agricultural Experiment Station Hatch Project 2052.

\section{LITERATURE CITED}

1. Altschul, S. F., Gish, W., Miller, W., Myers, E. W., and Lipman, D. J. 1990. Basic local alignment search tool. J. Mol. Biol. 215:403-410.

2. Bové, J. M., Whitcomb, R. F., and McCoy, R. E. 1983. Culture techniques for spiroplasmas from plants. Pages 225-234 in: Methods in Mycoplasmology. J. G. Tully and S. Razin, eds. Academic Press, Inc., New York.

3. Calavan, E. C., and Bové, J. M. 1989. Ecology of Spiroplasma citri. Pages 425-485 in: The Mycoplasmas. R. F. Whitcomb and J. G. Tully, eds. Academic Press, Inc., New York.

4. Calavan, E. C., and Oldfield, G. N. 1979. Symptomatology of spiroplasmal plant diseases. Pages 37-64 in: The Mycoplasmas. R. F. Whitcomb and J. G. Tully, eds. Academic Press, Inc., New York.

5. Clark, T. B., Whitcomb, R. F., Tully, J. G., Mouches, C., Saillard, C., Bové, J. M., Wroblewski, H., Carle, P., Rose, D. L., Henegar, R. B., and Williamson, D. L. 1985. Spiroplasma melliferum, a new species from the honeybee (Apis mellifera). Int. J. Syst. Bacteriol. 35:296-308.

6. Davis, R. E. 1978. Spiroplasma associated with flowers of the tulip tree (Liriodendron tulipifera L.). Can. J. Microbiol. 24:954-959.

7. Davis, R. E., and Fletcher, J. 1983. Spiroplasma citri in Maryland: Isolation from field-grown plants of horseradish (Armoracia rusticana) with brittle root symptoms. Plant Dis. 67:900-903.

8. Deeley, J., Stevens, W. A., and Fox, R. T. V. 1979. Use of Dienes' stain to detect plant diseases induced by mycoplasmalike organisms. Phytopathology 69:1169-1171.

9. Doyle, J. J., and Doyle, J. L. 1987. A rapid DNA isolation procedure for small quantities of fresh leaf tissue. Phytochemical Bull. 19:11-15.

10. Fawcett, H. S. 1946. Stubborn disease of citrus, a virosis. Phytopathology 36:675-677.

11. Felsenstein, J. 1989. PHYLIP - Phylogeny Inference Package (Version 3.2). Cladistics 5:164-166.

12. Fletcher, J. 1983. Brittle root of horseradish in Illinois and the distribution of Spiroplasma citri in the United States. Phytopathology 73:354-357.

13. Fletcher, J., Schultz, G. A., Davis, R. E., Eastman, C. E., and Goodman, R. M. 1981. Brittle root disease of horseradish: Evidence for an etiological role of Spiroplasma citri. Phytopathology 71:1073-1080.

14. Fletcher, J., Shaw, M. E., Baker, G. R., Dugan, K. J., Ye, F., Sha, Y., Zuck, P. D., and Myers, G. D. 1996. Molecular characterization of Spiroplasma citri BR3 lines that differ in transmissibility by the leafhopper Circulifer tenellus. Can. J. Microbiol. 42:124-131.

15. Fudl-Allah, A. E.-S. A., Calavan, E. C., and Igwegbe, E. C. K. A. 1972. Culture of a mycoplasmalike organism associated with stubborn disease of citrus. Phytopathology 62:729-731.
16. Gumpf, D. G., and Calavan, E. C. 1981. Stubborn disease of citrus. Pages 97-134 in: Mycoplasma Diseases of Trees and Shrubs. K. Maramorosch and S. P. Raychaudhuri, eds. Academic Press, Inc., New York.

17. Jacob, C., Nouzieres, F., Duret, S., Bové, J. M., and Renaudin, J. 1997. Isolation, characterization, and complementation of a motility mutant of Spiroplasma citri. J. Bacteriol. 179:4802-4810.

18. Koeuth, T., Versalovic, J., and Lupski, J. R. 1995. Differential subsequence conservation of interspersed repetitive Streptococcus pneumoniae BOX elements in diverse bacteria. Genome Res. 5:408-418.

19. Lee, I.-M., Bottner, K. D., Munyaneza, J. E., Davis, R. E., Crosslin, J. M., du Toit, L. J., and Crosby, T. 2006. Carrot purple leaf: A new spiroplasmal disease associated with carrots in Washington State. Plant Dis. 90:989-993.

20. Lee, I.-M., and Davis, R. E. 1983. New media for rapid growth of Spiroplasma citri and corn stunt spiroplasma. Phytopathology 74:84-89.

21. Liu, H.-Y., Gumpf, D. J., Oldfield, G. N., and Calavan, E. C. 1983. The relationship of Spiroplasma citri and Circulifer tenellus. Phytopathology 73:585-590.

22. Louws, F. J., Rademaker, J. L. W., and Bruijn, F. J. 1999. The three Ds of PCR-based genomic analysis of phytobacteria: Diversity, detection, and disease diagnosis. Annu. Rev. Phytopathol. 37:81-125.

23. Melcher, U., and Fletcher, J. 1999. Genetic variation in Spiroplasma citri. Eur. J. Plant Pathol. 105:519-533.

24. Mello, A. F. S., Yokomi, R. K., Melcher, U., Chen, J., and Fletcher, J. 2006. Assessment of genetic diversity in Spiroplasma citri by RAPD, repPCR and bacteriophage primers. (Abstr.) Phytopathology 96(suppl.):S77.

25. Mutaqin, K. H. 2004. Molecular typing of Spiroplasma species and lines using rep-polymerase chain reaction and transposome mutagenesis and selection of natural non-adherent mutants of Spiroplasma citri. Ph.D. thesis. Oklahoma State University, Stillwater.

26. Neyrolles, O., Chambaud, I., Ferris, S., Prevost, M.-C., Sasaki, T., Montagnier, L., and Blanchard, A. 1999. Phase variations of the Mycoplasma penetrans main surface lipoprotein increase antigenic diversity. Infect. Immun. 67:1569-1578.

27. Oldfield, G. N., Kaloostian, G. H., Pierce, H. D., Calavan, E. C., Granett, A. L., Blue, R. L., Rana, G. L., and Gumpf, D. J. 1977. Transmission of Spiroplasma citri from citrus to citrus by Scaphytopius nitridus. Phytopathology 67:763-765.

28. Page, R. D. M. 1996. TREEVIEW: An application to display phylogenetic trees on personal computers. Comp. Appl. Biosci.12:357-358.

29. Pollack, S. L., Lin, B.-H., and Allshouse, J. 2003. Characteristics of U.S. orange consumption. Pages 1-17 in: Electronic Outlook Report from the Economic Research Service USDA.

30. Qin, X., Miranda, V. S., Machado, M. A., Lemos, E. G. M., and Hartung, J. S. 2001. An evaluation of the genetic diversity of Xylella fastidiosa isolated from diseased citrus and coffee in São Paulo, Brazil. Phytopathology 91:599-605.

31. Saglio, P., L'hospital, M., Lafleche, D., Dupont, G., Bové, J. M., Tully, J. G., and Freundt, E. A. 1973. Spiroplasma citri gen. and sp. n.: A mycoplasma-like organism associated with "stubborn" disease of citrus. Int. J. Syst. Bacteriol. 23:191-204.

32. Sambrook, J., Fritsch, E. F., and Maniatis, T., eds. 1989. Molecular Cloning: A Laboratory Manual. Cold Spring Harbor Laboratory, Cold Spring Harbor, NY.

33. SAS Institute. 2003. The SAS System for Windows. Version 9.1. SAS Institute, Inc., Cary, NC.

34. Sha, Y., Melcher, U., Davis, R. E., and Fletcher, J. 1995. Resistance of Spiroplasma citri lines to the virus SVTS2 is associated with integration of viral DNA sequences into host chromosomal and extrachromosomal DNA. Appl. Environ. Microbiol. 61:3950-3959.

35. Skroch, P., and Nienhuis, J. 1995. Impact of scoring error and reproducibility of RAPD data on RAPD based estimates of genetic distance. Theor. Appl. Genet. 91:1086-1091.

36. Townsend, R., Markham, P. G., Plaskitt, K. A., and Daniels, M. J. 1977. Isolation and characterization of a non-helical strain of Spiroplasma citri. J. Gen. Microbiol. 100:15-21.

37. Tyler, K. D., Wang, G., Tyler, S. D., and Johnson, W. M. 1997. Factors affecting reliability and reproducibility of amplification-based DNA fingerprinting of representative bacterial pathogens. J. Clin. Microbiol. 35:339-346.

38. Wayadande, A. C., and Fletcher, J. 1995. Transmission of Spiroplasma citri lines and their ability to cross gut and salivary gland barriers within the leafhopper vector Circulifer tenellus. Phytopathology 85:1256-1259.

39. Ye, F., Laigret, F., Whitley, J. C., Citti, C., Finch, L. R., Carle, P., Renaudin, J., and Bové, J. M. 1992. A physical and genetic map of the Spiroplasma citri genome. Nucleic Acids Res. 20:1559-1565.

40. Ye, F., Melcher, U., Rascoe, J. E., and Fletcher, J. 1996. Extensive chromosome aberrations in Spiroplasma citri strain BR3. Biochem. Genet. 34:269-286.

41. Yokomi, R. K., Mello, A. F. S., Saponari, M., and Fletcher, J. 2008. PCRbased detection of Spiroplasma citri associated with citrus stubborn disease. Plant Dis. 92:253-260. 